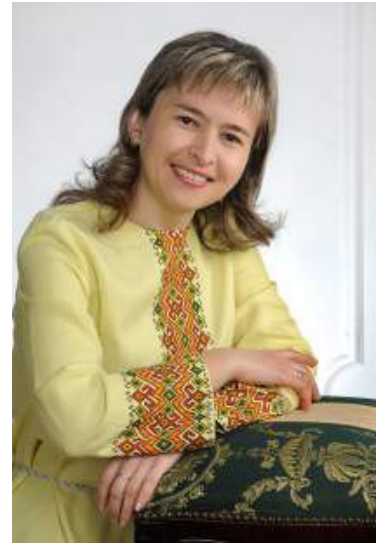

\section{Оксана Цюняк,}

кандидат педагогічних наук, доцент кафедри

педагогіки початкової освіти,

ДВНЗ «Прикарпатський національний університет імені Василя Стефаника»

(м. Івано-Франківськ, Україна)

\author{
Oksana Tsiuniak, \\ $\mathrm{PhD}$ in Education, Associate Professor, \\ Department of Pedagogy of Primary Education, \\ Vasyl Stefanyk Precarpathian National University \\ (Ivano-Frankivsk, Ukraine) \\ tsiuniak33@gmail.com
}

ORCID ID 0000-0002-4573-1865

Удк 378:001.895.372.4

\title{
ДЕЯКІ АСПЕКТИ ФОРМУВАННЯ ПРОФЕСІЙНОЇ ГОТОВНОСТІ МАЙБУТНІХ МАГІСТРІВ ПОЧАТКОВОЇ ОСВІТИ ДО ІННОВАЦІЙНОЇ ДІЯЛЬНОСТІ В ЗАКЛАДАХ ВИЩОЇ ОСВІТИ
}

Анотація. У статті акцентується увага на деяких аспектах формування готовності майбутніх магістрів початкової освіти до інноваційної діяльності у закладах вищої освіти. Мета статті - на основі узагальнення теоретичних та практичних засад професійної підготовки майбутніх магістрів початкової освіти обґрунтувати структурні компоненти, критерії та рівні їхньої готовності до інноваційної діяльності. Розкрито важливість урахування умов інноваційного освітнього середовища закладу вищої освіти щодо формування готовності майбутніх магістрів початкової освіти до інноваційної діяльності. Проаналізовано поняття інноваційного освітнього середовища; творча реалізація в освітньому процесі інноваційних технологій, спрямованих на формування готовності майбутніх магістрів початкової освіти до інноваційної діяльності. Емпіричне дослідження проводилось за допомогою використання методики «Здібності педагога до творчого саморозвитку» (І. Нікішина).

Ключові слова: інновації, інноваційна діяльність, майбутні магістри початкової освіти, заклад вищої освіти, професійна підготовка, творчий саморозвиток, інноваційне освітнє середовище.

\section{SOME ASPECTS OF FORMATION OF PROFESSIONAL READINESS OF FUTURE MASTERS OF PRIMARY EDUCATION TO INNOVATIVE ACTIVITY IN HIGHER EDUCATION INSTITUTIONS}

\footnotetext{
Abstract. The article focuses on some aspects of forming the readiness of future masters of elementary education for innovation activities in higher education institutions. The purpose of the article is to substantiate the structural components, criteria and levels of their readiness for innovation, basing on the generalization of theoretical and practical principles of professional training of future masters of elementary education. The importance of taking into account the conditions of the innovative educational environment of the institution of higher education regarding the formation of the readiness of future masters is revealed.

The concept of innovative educational environment, creative realization in the educational process of innovative technologies, aimed at forming the readiness of future masters of elementary education for innovation are analyzed. An empirical study was carried out using the method "Teacher's Ability to Creative Self-Development" (I. Nikishin).

Keywords: innovations, innovative activity, future masters of elementary education, institution of higher education, professional training, creative self-development, innovative educational environment.

\section{вСтуп}

Постановка проблеми. Сучасний етап розвитку суспільства характеризується динамічними інноваційними перетвореннями в усіх сферах життєдіяльності людства, у тому числі й освіті. Стратегічні напрями інноваційних перетворень у галузі освіти визначені в Законах України «Про освіту» (2017), «Про вищу освіту» (2014), «Про інноваційну діяльність», Національній доктрині розвитку освіти України у XXI столітті (2002), Національній стратегії розвитку освіти в Україні на 2012-2021 роки (2014); Концепції Нової української школи (2016), Державному стандарті початкової освіти (2018), Наказі «Про внесення змін до Положення про порядок здійснення інноваційної діяльності в системі освіти України» (2015).
} 
Сьогодні у системі вищої освіти України спостерігається тенденція до посилення інноваційності у сфері підготовки педагогічних кадрів, зокрема майбутніх магістрів початкової освіти. Адже розвиток науковотехнічного прогресу, глобалізація і швидкоплинність змін сучасного суспільства потребує нової генерації спеціалістів, котрі: здатні швидко засвоювати і ефективно використовувати останні досягнення науки і техніки, що невпинно і стрімко розвиваються; уміють вирішувати нестандартні проблеми, що виникають у процесі їхньої професійної діяльності, та вдосконалювати свої професійні якості.

Слід зазначити, що майбутній магістр початкової освіти є водночас викладачем, учителем, організатором початкової освіти, активним учасником спілкування з учнями, батьками, колегами, дослідником педагогічного процесу, громадським діячем. Сучасні заклади освіти потребують фахівця, який не лише орієнтується в освітніх інноваціях, але й застосовує їх у своїй роботі, здатний до самореалізації та самостійного інноваційного пошуку, має високий рівень готовності до інноваційної діяльності, уміє генерувати оригінальні й ефективні для суспільства і сучасної школи ідеї, приймати оптимальні рішення в нетипових умовах, креативно мислити тадіяти.

Формування готовності майбутніх магістрів початкової освіти до інноваційної професійної діяльності стає можливим за умов здійснення цілеспрямованої, спеціально організованої підготовки в закладах вищої освіти. Однак існує реальна суперечність: з одного боку, є законодавча та наукова база щодо інноваційних підходів до вирішення проблем сучасної освіти, з іншого, - цей процес гальмується недостатністю підготовки майбутніх фахівців до створення та впровадження інновацій. Тому формування готовності майбутніх магістрів початкової освіти до інноваційної діяльності $є$ актуальною проблемою сучасності та має важливе педагогічне і соціальне значення.

\section{МЕТА І ЗАВДАННЯ ДОСЛІДЖЕННЯ}

Мета статті - на основі узагальнення теоретичних та практичних засад професійної підготовки майбутніх магістрів початкової освіти обґрунтувати структурні компоненти, критерії та рівні їхньої готовності до інноваційної діяльності.

Завдання:

1. Уточнити зміст поняття «інноваційне освітнє середовище» «інноваційна діяльність», «готовність майбутніх магістрів початкової освіти до інноваційної діяльності».

2. Розробити компоненти, критерії та рівні готовності майбутніх магістрів початкової освіти до інноваційної діяльності.

3. Здійснити діагностику рівня готовності майбутніх магістрів початкової освіти до інноваційної діяльності в закладах вищої освіти.

\section{МЕТОДИ ДОСЛІДЖЕННЯ}

Для вирішення поставлених завдань використано теоретичні методи: аналіз і систематизація психологопедагогічної та навчально-методичної літератури з метою визначення стану теоретичного обґрунтування проблеми формування готовності майбутніх магістрів початкової освіти до інноваційної діяльності у закладах вищої освіти. Методи емпіричного дослідження: педагогічні спостереження, бесіди, анкетування, тестування, педагогічний експеримент.

\section{РЕЗУЛЬТАТИ ДОСЛІДЖЕННЯ}

На сучасному етапі розвитку цивілізації особливу роль відіграє інноваційний потенціал суспільства, що зумовлює потребу в людях, здатних системно мислити, створювати принципово нові ідеї в різних галузях знань. Інновації в освіті - процес творення, запровадження й поширення в освітній практиці нових ідей, засобів, педагогічних та управлінських технологій, у результаті яких підвищуються показники (рівні) досягнень структурних компонентів освіти, відбувається перехід системи до якісно іншого стану [3, с. 339]. Як показує досвід, інноваційна діяльність є важливим складником сучасних реформ в освіті й одним із суттєвих чинників переходу до моделі інноваційного розвитку України загалом.

Сьогодні заклад вищої освіти виступає генератором ідей, моделей педагогічної діяльності, ініціатором і провідником інноваційних процесів в освітньому просторі. Зауважимо, що професійна підготовка майбутніх магістрів початкової освіти в умовах університету відповідатиме сучасному рівню тоді, коли зміст, фрорми і методи фахової, методичної та психолого-педагогічної підготовки будуть зорієнтовані на формування «інноваційного фахівця». Це забезпечується взаємозв'язком навчально-пізнавальної, наукової, пошуково-дослідницької та практичної підготовки майбутніх педагогів.

Доречно зазначити, що однією з вимог до інноваційності в системі освіти є формування інноваційного освітнього середовища. А. Каташов узагальнив різноманітні підходи до визначення поняття «освітнє середовище навчального закладу» та розглядає його як сукупність духовно-матеріальних умов функціонування закладу освіти, що забезпечують саморозвиток вільної й активної особистості, реалізацію творчого потенціалу студентів. Під «освітнім інноваційним середовищем» автор розуміє навчальне середовище, яке будується на принципах кооперації навчальної діяльності як рівноправної взаємодії студентів у невеликих групах, що об'єднуються для вирішення загального завдання і спільними зусиллями досягають взаємної згоди [6, 20 с.]. Н. Разіна стверджує, що інноваційне освітнє середовище - це комплекс взаємопов'язаних умов, які забезпечують освіту людини, формування особистості педагога з інноваційно-творчим мисленням, його професійну компетентність [10, с. 56]. На думку О. Шапран, інноваційне освітнє середовище - це педагогічно доцільно організований простір життєдіяльності, який сприяє розвитку інноваційного ресурсу особистості; інтегрований засіб накопичення і реалізації інноваційного потенціалу навчального закладу [12]. Л. Ващенко наголошує на тому, що головна місія 
такого середовища полягає в генеруванні інноваційних потоків та нарощуванні інноваційного потенціалу кожного навчального закладу й системи загалом, збереження і локальних, і адміністративних новацій [1, с. 38].

Оцінка ефективності освітнього інноваційного середовища здійснюється за різними показниками 3 урахуванням структури даного френомена. Так, А. Каташов виділяє наступні параметри:

- результативність діяльності навчального закладу (рівень знань і загальнокультурного розвитку студентів; ступінь привабливості освітнього закладу й освітніх послуг; ступінь засвоєння нових технологій, програм, методик; взаємодія з вузами);

- комфортність (естетика середовища, санітарно-гігієнічне, фрізіологічне обґрунтування режиму роботи; наявність ситуації вибору змісту, форм освіти; соціально-психологічний мікроклімат);

- забезпеченість навчальної діяльності (навчально-матеріальне обладнання, рівень організаційнофункціональної забезпеченості);

- характеристика кадрового потенціалу;

- рівень і характер управлінської діяльності [6].

Варто зазначити, що досі немає чітко визначених структурних компонентів інноваційного освітнього середовища. Але важливим $€$ те, що науковці, вивчаючи компоненти інноваційного освітнього середовища, визначають особистість як найважливіший його елемент, як складну й відкриту систему, що постійно саморозвивається.

У контексті інноваційної стратегії навчально-виховного процесу у закладах вищої освіти суттєво зростає роль викладача, який забезпечує професійну підготовку майбутнього фрахівця як безпосереднього носія новаторських ідей. Соціально-психологічна та професійна готовність викладача до творчої діяльності передбачає відкритість, багатоваріантність, гнучкість і динамізм, орієнтує на використання різноманітних форм роботи зі студентами. Викладач може виступати як автор, розробник, дослідник, користувач і пропагандист нових педагогічних технологій та теорій [1, с. 3-4). Успішне використання викладачем педагогічних інновацій вимагає моделювання й оптимізації процесів створення, засвоєння і застосування нових ідей та технологій. Етап створення педагогічних інновацій включає: визначення нового в системі педагогічних інновацій; опис, пояснення сутності педагогічного нововведення; визначення сукупності об'єктивних і суб'єктивних умов для оптимальної реалізації нових ідей; зіставлення пропонованого нового з прийнятими критеріями педагогічних інновацій; локальне використання педагогічної інновації та її експертна оцінка. У роботі викладача закладу вищої освіти ефективними $є$ такі форми роботи:

- відвідання відкритої лекції викладача, який використовує передові технології навчання, 3 подальшим аналізом;

- повідомлення викладачем про педагогічну знахідку, нові прийоми і способи роботи на засіданні науковометодичного семінару;

- використання записаних на відеомагнітофон лекцій, практичних занять, які проводили викладачі -ініціатори запровадження нового у процесі професійної підготовки фахівців;

- виступи викладача про досвід роботи колег на основі відвідування занять, бесід, спостережень;

- робота над навчальними посібниками, дисертаціями, монографіями з аналізом педагогічних інновацій.

Необхідно зазначити, що особливості поняття «інноваційна діяльність» розкриваються не тільки через аспекти оновлення традиційної системи навчання, а через характеристику індивідуального стилю діяльності педагога-новатора. Педагог, підготовлений до інноваційної професійної діяльності, володіє такими професійними й особистісними якостями, як: усвідомлення цілей освітньої діяльності в контексті актуальних педагогічних проблем; осмислена в контексті сучасності педагогічна позиція, уміння відповідно до нововведень у науці і практиці по-новому формулювати освітні цілі з предмета, певної методики, досягати й оптимально переосмислювати їх під час навчання; здатність вибудовувати цілісну освітню програму навчання й виховання, яка враховувала б індивідуальний підхід до дітей, освітні стандарти, нові педагогічні орієнтири; вміле поєднання вчителем реальних умов з вимогами особистісно зорієнтованої освіти, коригування освітнього процесу за критеріями інноваційної діяльності; здатність бачити індивідуальні здібності дітей і навчати відповідно до їхніх особливостей; уміння продуктивно, нестандартно організувати освітній процес, забезпечуючи розвиток творчості учнів через використання інноваційних технологій; застосування форм і методів інноваційного навчання, яке передбачає врахування особистого досвіду і мотивів вихованців; уміння аналізувати зміни в освітній діяльності.

Л. Даниленко розглядає інноваційну діяльність як процес «внесення нових елементів у традиційну систему, створення та використання інтелектуального продукту, реалізації нових оригінальних ідей у формі готового товару (послуги) на ринку; інноваційна освітня діяльність відповідно є процесом внесення якісно нових елементів в освіту» [3, с. 95].

У світлі нових вимог до особистості випускника закладу вищої освіти пріоритетними мають бути такі якості, як: компетентність, інноваційність, мобільність, індивідуальність, конструктивність.

У педагогічній літературі поняття «професійна готовність» має декілька значень. Найбільш поширеним є тлумачення: організовувати щось; навчити тому, що необхідно; дати необхідні знання.

Розуміння поняття «готовність» у багатьох дослідників залежить від основних методологічних парадигм та теоретичних підходів. Учений Н. Левітов розглядає готовність на функціональному рівні та визначає ії̈ як 
особливий психічний стан, цілісний прояв особистості [7, с. 131]. Сучасні дослідники М. Дяченко, Л. Кандибович характеризують готовність і як стан, і як інтегративну якість особистості. Вчені стверджують, що стан готовності $€$ «настроєм» - пристосуванням можливостей особистості для успішних дій у певний [5]. В. Сластьонін розглядає професійну готовність як складний синтез взаємопов'язаних структурних компонентів: психологічна готовність (сформована спрямованість на педагогічну діяльність, установка на роботу в школі); науково-теоретична готовність (наявність необхідного обсягу педагогічних, психологічних, соціальних знань, необхідних для компетентної педагогічної діяльності); практична готовність (наявність сформованих на належному рівні професійних знань і вмінь); психофізіологічна готовність (наявність відповідних передумов для оволодіння педагогічною діяльністю, сформованість професійно значущих якостей); фрізична А. Линенко визначає готовність до діяльності як інтегроване системою властивостей і відносин утворення особистості, що характеризує її вибіркову прогнозуючу активність при підготовці та включені до діяльності [8, с. 129]. Дослідник вважає, що така готовність виникає в результаті певного досвіду людини, який ґрунтується на формуванні позитивного ставлення до діяльності, усвідомленні мотивів і потреб у цій діяльності. На думку І. Дичківської, готовність до інноваційної педагогічної діяльності - особливий особистісний стан, що передбачає наявність у педагога мотиваційно-ціннісного ставлення до професійної діяльності, володіння ефективними способами і засобами досягнення педагогічних цілей, здатності до творчості та рефлексії. Авторка пропонує визначати готовність до інноваційної педагогічної діяльності за такими показниками: усвідомлення потреби запровадження педагогічних інновацій на рівні власної педагогічної практики; інформованість про новітні педагогічні технології, знання новаторських методик роботи; зорієнтованість на створення власних творчих завдань, методик, проведення експериментальної роботи; готовність до подолання труднощів, пов'язаних зі змістом та організацією інноваційної діяльності; володіння практичними навичками освоєння педагогічних інновацій та створення нових [4].

Профресійна підготовка майбутніх магістрів початкової освіти до інноваційної діяльності у закладах вищої освіти повинна починатися з формування в них ціннісного ставлення до майбутньої професійної діяльності, наявності відповідних мотивів, індивідуально-особистісних та соціокультурних фракторів, формування особистісного та науковопедагогічного світогляду, володіння комплексом науково-інноваційних методів, усвідомлення своєї професійної неповторності, бажання передачі досвіду іншим, здатності до інтеграції наукових знань, вільного володіння хоча б однією іноземною мовою, участі у міжнародних наукових проектах, метою яких є комплексне всебічне осмислення освітянського досвіду та найкращих практик у сфері європейських інтеграційних досліджень в Україні. У закладах вищої освіти повинні створюватися відповідні умови для підготовки компетентного фрахівця, зорієнтованого на інноваційну діяльність, постійний професійний розвиток, що забезпечить у подальшому високий рівень конкурентоспроможності, продуктивності професійної діяльності і, як наслідок, - кар'єрне зростання та самореалізацію.

Учасники інноваційного процесу, крім готовності і прагнення впроваджувати новації, повинні мати належну кваліфікацію для виконання покладених на них обов'язків. Як свідчить практика, нерідко буває, що педагог може успішно реалізувати в навчальному процесі вимоги програми, володіти різноманітними методиками навчання й виховання, але при цьому не відчувати потреби в нововведеннях саме через відсутність у структурі особистості творчого потенціалу. Тому необхідною умовою ефективної інноваційної діяльності є спеціальна підготовка педагога, осмислення ним досвіду такої діяльності, внутрішня налаштованість на пошук та осягнення нового. Об'єктивним процесом цілеспрямованої підготовки магістрів до апробації, впровадження педагогічних інновацій є: їхня адаптація до навчання у закладах вищої освіти та формування мотивації до фахової діяльності; використання інноваційних методів у процесі вивчення дисциплін професійно зорієнтованого та практичного циклів підготовки, надання навчальному процесу творчого, інноваційного характеру; поглиблення інтеграції психолого-педагогічних та методичних дисциплін; фундаменталізація підготовки з урахуванням специфіки діяльності майбутніх магістрів початкової освіти; застосування в навчальному процесі інноваційних інформаційних технологій; використання системного принципу навчання майбутніх фахівців проектування, створення і часткової перевірки моделей роботи у вигляді загальної схеми або плану діяльності.

\section{Результати емпіричного дослідження}

Необхідною умовою здійснення інноваційної діяльності є цілеспрямована організація процесу професійної підготовки майбутніх магістрів початкової освіти в закладах вищої освіти, оскільки «... інновації - це цілеспрямована реалізація того потенціалу, який міститься у творчості особистості» [9, с. 154-162].

Теоретичний аналіз досліджуваної проблеми дозволив виокремити один із основних компонентів готовності майбутніх магістрів початкової освіти до інноваційної діяльності, а саме: особистісний компонент (здібності до творчого саморозвитку). Кожен майбутній магістр початкової освіти повинен розвивати здібності, керувати особистим удосконаленням та удосконаленням інших, забезпечувати перспективу внутрішнього росту, творчо підходити до вирішення складних професійних ситуацій і виявляти вміння діяти не за зразком, а оригінально, передбачати новизну при прийнятті рішень, вміти реалізувати свій творчий потенціал. Для визначення здібностей майбутніх магістрів початкової освіти до творчого саморозвитку використано методику «Здібності педагога до творчого саморозвитку» (І. Нікішина).

У процесі професійної підготовки у майбутніх магістрів початкової освіти проявляються здібності й уміння, якими визначається рівень професійної інноваційної діяльності. Наявність творчих здібностей у майбутніх магістрів початкової освіти є важливим чинником професіоналізму, передумовою досягнення успіху у майбутній інноваційній діяльності. Аналіз здібностей особистості дозволяє виявити їхню психологічну структуру, виокремити такі компоненти, які можуть бути індикаторами відповідних здібностей і сприяти фрормуванню 
готовності до інноваційної діяльності. Аналіз науково-педагогічних досліджень, власні спостереження дають змогу визначити два рівні готовності до інноваційної діяльності: достатній і високий.

При визначенні вибіркової сукупності (необхідної кількості магістрантів для здійснення експерименту) нами було задіяно магістрантів педагогічного факультету Прикарпатського національного університету імені Василя Стефаника. Для досягнення достовірності результатів дослідження ми визначили мінімально необхідну кількість магістрантів, яка була задіяна в експериментальному дослідженні. Перед початком анкетування ми умовно поділили магістрантів на дві групи - контрольну (КГ) та експериментальну (ЕГ). Оскільки нами визначено два рівні сформованості готовності до інноваційної діяльності - достатній і високий, ми узгодили їх зі шкалою анкети. До достатнього рівня віднесено відповіді, які налічують від 15 до 54 балів - зупинений саморозвиток; відсутня система саморозвитку; до високого - від 55 до 75 балів - активний саморозвиток.

У процесі експериментального дослідження респондентам пропонувалося відповісти на низку запитань. Кожному варіанту відповіді відповідає бальна оцінка за п'ятирозрядною шкалою.

Результати дослідження показали, що 75\% (69 магістрантів від загальної кількості 92 осіб контрольної групи) мають достатній рівень прояву здібностей до творчого саморозвитку; 25\% (23 магістранти) - високий рівень прояву здібностей до творчого саморозвитку (див. рис. 1).

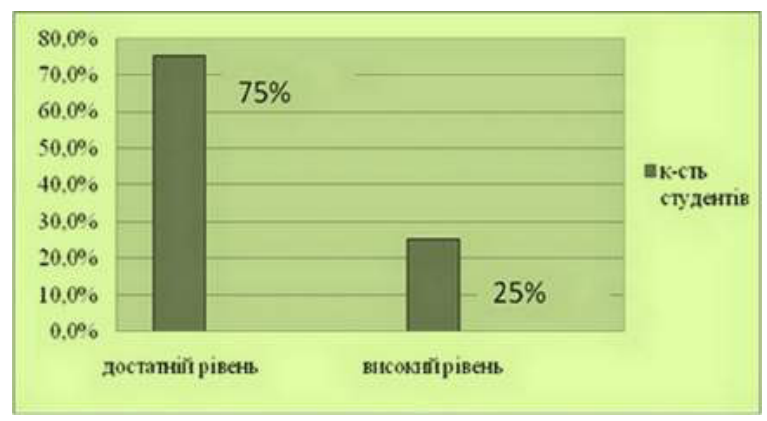

Рис. 1. Рівні прояву здібностей до творчого саморозвитку КГ

Відповідно до окресленого вище алгоритму ми визначили рівні експериментальної групи (88 осіб) на етапі констатувального експерименту. Виявилося, що 26,1\% (23 магістранти) експериментальної групи мають достатній рівень прояву здібностей до творчого саморозвитку; 73,9\% (65 магістрантів ) - високий рівень прояву здібностей до творчого саморозвитку (див. рис. 2).

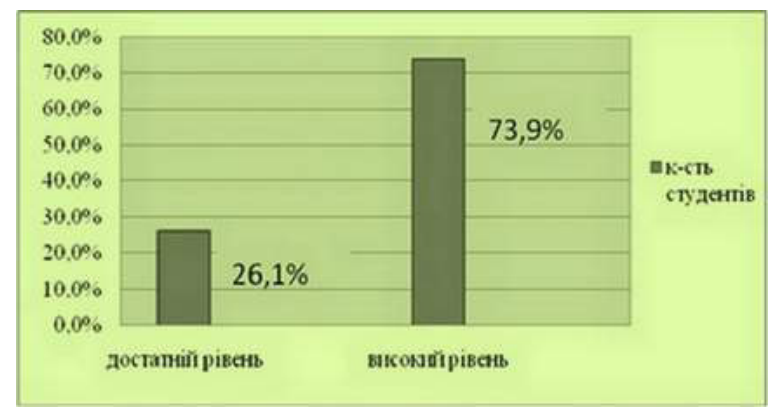

Рис. 2. Рівні прояву здібностей до творчого саморозвитку ЕГ

Результати констатувального етапу педагогічного експерименту дозволили зробити загальний висновок про потребу вдосконалювати рівень готовності до інноваційної діяльності майбутніх магістрів початкової освіти у 3ВО.

\begin{tabular}{|c|c|c|c|}
\hline \multirow{2}{*}{ Групи магістрантів } & \multirow{2}{*}{ Рівні } & \multicolumn{2}{|c|}{ Здібності до творчого саморозвитку } \\
\hline & & К-СТЬ & $\%$ \\
\hline \multirow{2}{*}{$\begin{array}{c}\mathrm{K} \Gamma \\
\mathrm{n}_{1}=92\end{array}$} & Високий & 23 & 25 \\
\hline & Достатній & 69 & 75 \\
\hline \multicolumn{2}{|l|}{ Всього } & & 92 \\
\hline \multirow{2}{*}{$\begin{array}{c}E \Gamma \\
n_{2}=88 \\
\end{array}$} & Високий & 65 & 73,9 \\
\hline & Достаній & 23 & 26,1 \\
\hline \multicolumn{2}{|l|}{ Всього } & 88 & 100 \\
\hline
\end{tabular}

Загальна характеристика рівнів готовності майбутніх магістрів початкової освіти до інноваційної діяльності (КГ та ЕГ) на етапі констатувального експерименту 
Як видно з таблиці, більшість магістрантів усвідомлюють необхідність розвитку рівня готовності до інноваційної діяльності. Проте на сучасному етапі організація навчально-виховного процесу у ЗВО поки що не спрямована на систематичну роботу з формування готовності до інноваційної діяльності.

Аналіз результатів формувального експерименту показав, що в експериментальній групі, порівняно 3 констатувальним експериментом, значно зросла кількість майбутніх магістрів початкової освіти із високим рівнем ціннісних орієнтацій - з 58 (65,9\%) до 69 (78,4 \%) осіб. Кількість магістрантів з достатнім рівнем зменшилась 3 30 (34,1\%) до 19 (21,6 \%). Кількість магістрантів із високим рівнем мотивації професійної діяльності збільшилася з 63 (71,6 \%) до 82 (93,2 \%) осіб. Кількість магістрантів із достатнім рівнем зменшилася 325 (28,4\%) до 6 $(6,8 \%)$ магістрантів. Кількість магістрантів із високим рівнем здібностей до творчого саморозвитку збільшилася з 65 (73,9 \%) до 81 (92 \%); із достатнім рівнем зменшилася відповідно з 23 (26,1%) до 7 (8 \%).

Аналізуючи отримані дані, ми дійшли висновку, що проблема формування готовності майбутніх магістрів початкової освіти до інноваційної діяльності залишається актуальною.

\section{ВИСНОВКИ ТА ПЕРСПЕКТИВИ ПОДАЛЬШИХ ДОСЛІДЖЕНЬ}

Таким чином, формування готовності майбутніх магістрів початкової освіти до інноваційної професійної діяльності стає можливим за умов здійснення цілеспрямованої, спеціально організованої підготовки у закладах вищої освіти, важливими аспектами якої $€$ : розуміння необхідності використання інноваційних ідей, інноваційних методів та технологій навчання, прагнення досягти успіху в інноваційній діяльності; урахування інноваційного освітнього середовища закладу вищої освіти (наявність відповідної матеріальної і навчальнометодичної бази, відображення ідей щодо використання педагогічних інновацій у методиці викладання навчальних дисциплін); обґрунтування змісту, фрорм, методів та засобів професійної підготовки майбутніх магістрів початкової освіти до інноваційної діяльності у закладах вищої освіти; творча реалізація в освітньому процесі інноваційних технологій, спрямованих на формування готовності майбутніх магістрів початкової освіти до інноваційної діяльності.

\section{СПИСОК ВИКОРИСТАНИХ ДЖЕРЕЛ}

[1] Ващенко Л. Інноваційне середовище післядипломної педагогічної освіти. Післядипломна освіта. 2012. № 1. URL: http:// www. sportpedagogy.org.ua/html/journal/2010-09/10soitpt.pdf.

[2] Ващенко Л. Рівні розвитку інноваційного середовища. Директор школи. 2008. № 5. С. 3-4.

[3] Даниленко Л. Менеджмент інновацій в освіті. Київ: Шкільний Світ, 2007. 120 с.

[4] Дичківська І. М. Основи педагогічної інноватики: навч. посіб. Рівне : Зелент. 2001. 222 с.

[5] Дьяченко М. Л, Кандибович Л. А. Психологические проблемы готовности к деятельности. Минск: Изд-во БГУ, 1976.176 с.

[6] Каташов А. І. Педагогічні основи розвитку інноваційного освітнього середовища сучасного ліцею: автореф. дис. .......кандидата пед. наук: Луганськ, 2001. 20 с.

[7] Левитов Н. Д. Психологическое состояние беспокойства, тревоги. Вопросы психологии. 1969. № 1. С.131-138.

[8] Линенко А. Ф. Готовність майбутнього вчителя до педагогічної діяльності. Педагогіка і психологія. 1995. № 1. С.125-132.

[9] Огієнко О. І. Формування готовності до інноваційної діяльності як важлива складова професійної підготовки майбутнього вчителя. Педагогічні науки: теорія, історія, інноваційні технології, наук. журнал СумДПУ імені А.С. Макаренка. № 7 (33) 2014. С. $154-162$.

[10] Разіна Н. О. Акмеологічний підхід до розвитку професіоналізму сучасного педагога в інноваційному освітньому середовищі середньої школи. Вісн. наук. шк. педагогів «АКМЕ». 2009. Вип. 3. http://www. sportpedagogy.org.ua/html/journal/2010- 09/10soitpt.pdf.

[11] Сластёнин В. А, Подымова Л. С. Педагогика: инновационная деятельность. Москва: Магистр, 2003. 308 с.

[12] Шапран О. І. Створення інноваційного освітнього середовища в процесі професійної підготовки майбутнього вчителя. URL:http://www. sportpedagogy.org.ua/html/journal/2010-09/10soitpt.pdf].

\section{REFERENCES (TRANSLATED AND TRANSLITERATED)}

[1] Vashhenko L. Innovacijne seredovyshhe pisljadyplomnoji pedaghoghichnoji osvity (Innovative environment of postgraduate pedagogical education). Pisljadyplomna osvita. 2012. № 1. URL: http://www. sportpedagogy.org.ua/html/journal/201009/10soitpt.pdf. (in Ukrainian)

[2] Vashhenko L. Rivni rozvytku innovacijnogho seredovyshha (Levels of innovation environment development). Dyrektor shkoly. 2008. № 5. S. 3-4. (in Ukrainian)

[3] Danylenko L. Menedzhment innovacij v osviti (Management of innovations in education). Kyjiv: Shkiljnyj Svit, 2007.120 s. (in Ukrainian)

[4] Dychkivsjka I. M. Osnovy pedaghoghichnoji innovatyky (Fundamentals of pedagogical innovation): navch. posib. Rivne : Zelent. 2001. 222 s. (in Ukrainian)

[5] Djjachenko M. L, Kandybovych L. A. Psykhologhycheskye problemy ghotovnosty k dejateljnosty (Psychological problems of readiness for activity). Mynsk: Yzd-vo BGhU, 1976. 176 s. (in Ukrainian)

[6] Katashov A. I. Pedaghoghichni osnovy rozvytku innovacijnogho osvitnjogho seredovyshha suchasnogho liceju (Pedagogical bases of development of innovative educational environment of modern lyceum): avtoref. dys.........kandydata ped. nauk: Lughansjk, 2001. 20 s. (in Ukrainian)

[7] Levytov N. D. Psykhologhycheskoe sostojanye bespokojstva, trevoghy (The psychological state of anxiety, anxiety). Voprosy psykhologhyy. 1969. № 1. S.131-138. (in Russian)

[8] Lynenko A. F. Ghotovnistj majbutnjogho vchytelja do pedaghoghichnoji dijaljnosti (Readiness of the future teacher to pedagogical activity). Pedaghoghika i psykhologhija. 1995. № 1. S.125-132. (in Ukrainian) 
[9] Oghijenko O. I. Formuvannja ghotovnosti do innovacijnoji dijaljnosti jak vazhlyva skladova profesijnoji pidghotovky majbutnjogho vchytelja (Formation of preparedness for innovation as an important component of the future teacher's professional training). Pedaghoghichni nauky: teorija, istorija, innovacijni tekhnologhiji, nauk. zhurnal SumDPU imeni A.S. Makarenka. № 7 (33) 2014. S. 154-162. (in Ukrainian)

[10] Razina N. O. Akmeologhichnyj pidkhid do rozvytku profesionalizmu suchasnogho pedaghogha $v$ innovacijnomu osvitnjomu seredovyshhi serednjoji shkoly (Acmeological Approach to the Development of the Professionalism of a Modern Teacher in an Innovative Educational Environment of High School). Visn. nauk. shk. pedaghoghiv «AKME». 2009. Vyp. 3. http://www. sportpedagogy.org.ua/html/journal/2010-09/10soitpt.pdf. (in Ukrainian)

[11] Slastënyn V.A, Podыmova L. S. Pedaghoghyka: ynnovacyonnaja dejateljnostj (Pedagogy: innovative activity). Moskva: Maghystr, 2003. 308 s. (in Russian)

[12] Shapran O. I. Stvorennja innovacijnogho osvitnjogho seredovyshha v procesi profesijnoji pidghotovky majbutnjogho vchytelja (Creation of an innovative educational environment in the process of professional training of the future teacher). URL:http://www. sportpedagogy.org.ua/html/journal/2010-09/10soitpt.pdf]. (in Ukrainian) 